\title{
https://doi.org/10.46813/2021-134-018 \\ EXPERIMENTAL TESTING BENCH FOR THE DIAGNOSTICS OF PLASMA GENERATED BY PULSED GUNS WITH THE DIELECTRIC SURFACE BREAKDOWN
}

\author{
D.V. Vinnikov, V.V. Katrechko, V.B. Yuferov, V.I. Tkachev, S.A. Petrenko, V.T. Fomin \\ National Science Center “Kharkov Institute of Physics and Technology”, Kharkiv, Ukraine \\ E-mail: vinnikov@kipt.kharkov.ua
}

The experimental testing bench "ETB-PG" was designed to study the operation of plasma guns. The constructional design of plasma guns with replaceable dielectric operating on the surface sparkover basis has been proposed. Discharge currents and voltages under atmospheric and vacuum conditions have been determined. The two types of discharges were detected in the pressure range varying from the atmospheric value to $10^{-5}$ Torr. An experimental Paschen curve has been plotted. A statistical dependence of the types of discharges on the number of pulses, the pressure in the chamber, and the breakdown voltage has been established. The results of optical studies of the plasma flow generated by plasma guns in the vacuum of $2 \cdot 10^{-4}$ to $2 \cdot 10^{-5}$ Torr have been presented. The propagation velocity of the plasma flow in axial and radial directions has been measured. The glow time of the injected plasma was determined for different types of the discharges. The spectrograms of the composition and degree of the plasma ionization have been obtained.

PACS: 52.50Dg, 52.80 Vp, 52.70Kz, 29.30Ep

\section{INTRODUCTION}

Plasma guns (PG) are the devices that provide the formation of plasma flows and their injection into free or closed spaces [1, 2]. Plasma flows have a wide range of the parameters that are defined both by the PG structure and electric circuit parameters including the external conditions of the operating medium [3]. The velocity of ions is in the range of $10^{6}$ to $10^{8} \mathrm{~cm} / \mathrm{s}$; the densities are in the range of $10^{14}$ to $10^{18} \mathrm{~cm}^{-3}$ at the duration of 0.1 to $100 \mu \mathrm{m}$ [4]. In this research paper, the PGs with the electric surface breakdown are used for the creation of the plasma cutoff jumper. It provides the voltage multiplication in the high-current electronic accelerators (HEA) based on inductive energy storage (IES) units. The voltage multiplication factor depends in many respects on the stability of the parameters of plasma flows generated by PGs. The parameters that have an overriding priority include the plasma flow propagation rate, the ion lifetime, the density, the temperature and the composition.

The purpose of this research was to define discharge circuit parameters and also the velocity, composition and the lifetime of generated plasma flows and the conditions that provide a stable operation of PGs in a wide pressure range.

\section{EXPERIMENTAL PROCEDURE}

The experimental testing bench "ETB PG" is shown in Fig. 1. Fig. 2 gives the schematic electrical diagram of the setup operation. We can see in Fig. 1 that PG are soldered to the frame of the section (3) that is actually the domain for the plasma confinement and diagnostics. The section diameter is $220 \mathrm{~mm}$ and the length of it is $600 \mathrm{~mm}$. The number of in-feeds for plasma guns is equal to 12. Each in-feed can be used both for the arrangement of the guns in it and/or for the placement of diagnostic tools. This section can also function as the waveguide and the plasma moves along it in the axial direction to the end flanges (10) and (5). The end flange (5) fulfills the same functions as the flange (10), in par- ticular it provides the visual control, the discharge video and photographic evidence; the diagnostic window (6) is intended for the insertion of the LEDs; (7) is the vacuum meter (VIT-2) and it is designed for the vacuum control during the experiment; (8) is the electrostatic kilovoltmeter C196 used for the diagnostics of the charge voltage of the capacitors; (9) is the box of charging resistors.

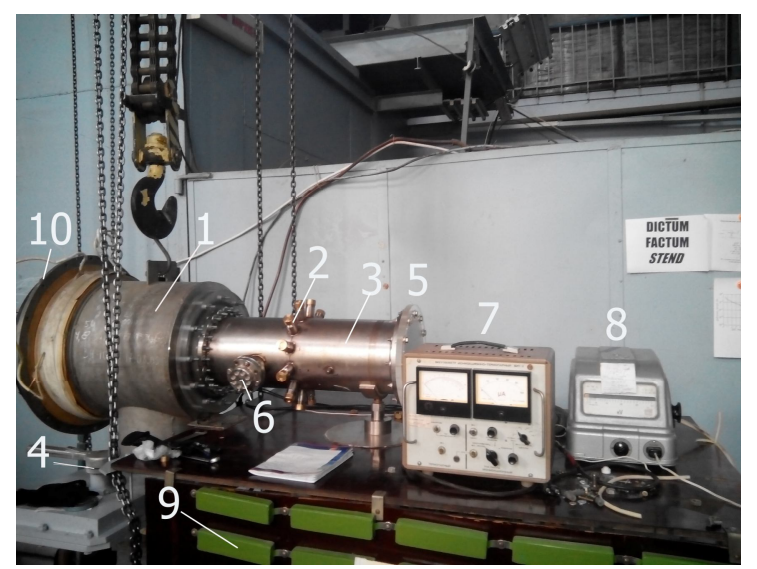

Fig. 1. General view of the experimental testing bench ("ETB $P G$ ")

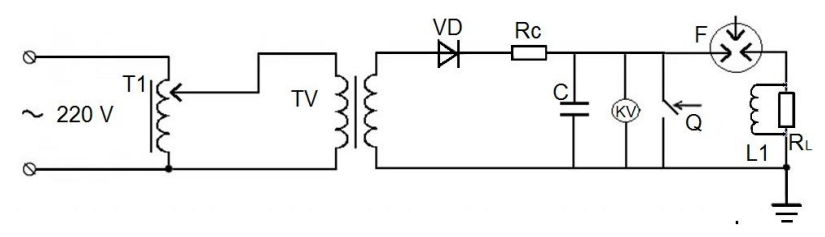

Fig. 2. Schematic electrical diagram of the experimental testing bench ("ETB PG")

The capacitor bank $C$ is charged by the d.c. voltage source formed by the following elements: the charging device in the form of the step-up high-voltage transformer UPS-70 and the auto-transformer; half-wave rectifier $V D$ in the form of series diode assemblies of a $\mathrm{KC}-201 \mathrm{E}$ type; the charging resistance $R c$ consisting of series resistors of a TVO-60 type with the equivalent resistance of $864 \mathrm{k} \Omega$. 
In the case of the operation of the discharger $F$ using no third electrode the charging voltage of the capacitor bank was controlled by the value of the interelectrode gap of the discharger $F$. The capacitor $\mathrm{C}$ was discharged onto the load in the form of the PG shunted by the inductance L. The suggested circuit provides the synchronous stable PG operation both in the mode of the discharger self-breakdown and in the case of the small-size ignition unit.

The discharge current was measured using the Rogowski coil with the sensitivity of $10 \mathrm{kA} / \mathrm{V}$. The discharge gap voltage was measured using the compensated capacitive-ohmic voltage divider "North Star High Voltage of a PVM-12 type" with the dividing coefficient of $1: 1000$, the carrying capacity of $80 \mathrm{MHz}$ and the maximum pulse voltage of $32 \mathrm{kV}$.

For the experiments that were carried out the pressure in the vacuum chamber was measured in the range varying from the atmospheric value to $2 \cdot 10^{-5}$ Torr. The pulsed plasma flow generated by the PG had the general energy input of 20 to $80 \mathrm{~J}$ and the operation frequency of up to $0.5 \mathrm{~Hz}$.

To reveal distinctive mechanisms of the discharge evolution under different vacuum conditions the processes were recorded by high-speed shooting using the digital photo-camera Casio Exilim EX-FH100 Black. The shooting rate in the video mode was 420 shots/s and 1000 shots/s. The plasma flow glow time and intensity and its longitudinal velocity were recorded by the sensors designed on the basis of photodiodes of a BPW34 TO-18 type with the operating range of 300 to $1100 \mathrm{~nm}$ and the current rise rate of $20 \mathrm{~ns}$.

The plasma flow velocity in the radial direction was judged by the difference of phases of the two sensors whose signal was processes by FEU-70 with the operation time of $0.1 \mu \mathrm{s}$. The spectral analysis was done using the two-channel spectrograph SL40-2-3648USB.

\section{THE EXPERIMENT SCENARIO}

Prior to the studies of the properties of the injected plasma the experiments were carried out that allowed us to define the parameters of the primary loop and the initial operation conditions of the PG. Breakdown voltages were defined for the insulating material in the absence of the initiating discharger in a wide range of vacuum values. Optimal vacuum conditions and the wanted parameters of the discharge circuit have been determined. Fig. 3 gives typical current oscillograms.
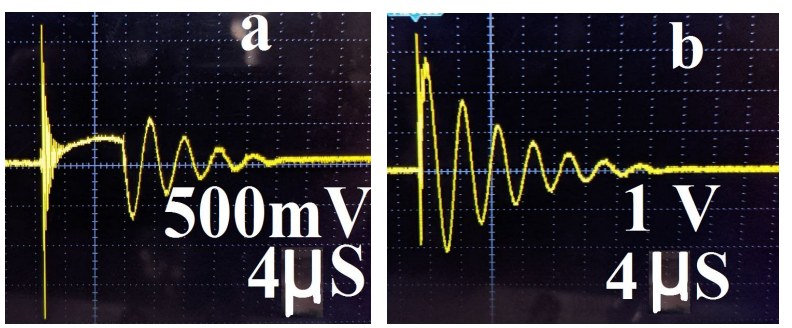

Fig. 3. Discharge current oscillograms for the two types of the discharges: $a$ - the space discharge; $b$ - the surface discharge

For the surface breakdown voltage of $14 \mathrm{kV}$ and the pressure of $5 \cdot 10^{-5}$ Torr the discharge current was equal to $\sim 7 \mathrm{kA}$. In this case, we observed a specific delay, i.e. the so-called bridge between the discharger operation and the master pulse of the PG.

With an increase in voltage up to 18 or $20 \mathrm{kV}$, the delay is disappeared and the current amplitude is increased nonlinearly attaining the values of 22 to $25 \mathrm{kA}$, as shown in Fig. 4. This effect can be explained by switching processes in the discharger and by the change in the discharge type that is related to a change in the parameters of the entire discharge loop.

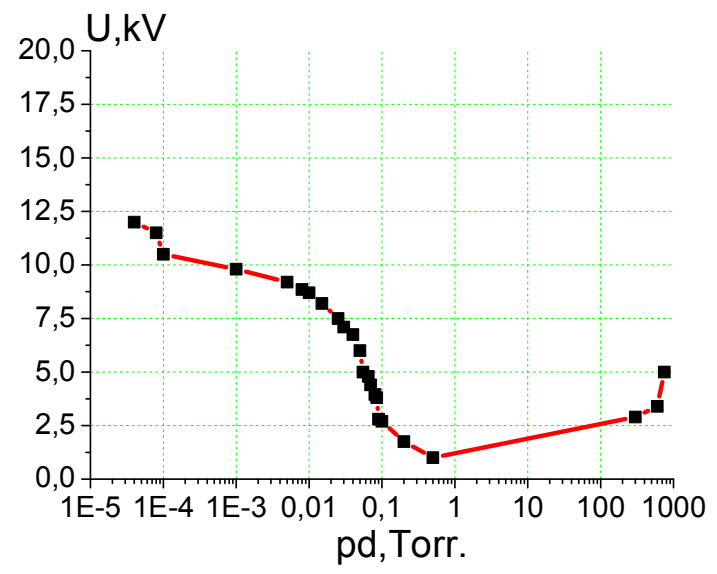

Fig. 4. The Paschen curve "ETB PG" $d=$ const (9 mm)

During the experiments carried out to define the breakdown voltages of $U_{b d}$ depending on vacuum conditions it was established that the minimum values of $U_{b d}$ varying from $800 \mathrm{~V}$ to $1.5 \mathrm{kV}$ are in the pressure range of $\mathrm{p}=1 \ldots 0.1$ Torr. In the pressure range of $2 \cdot 10^{-4} \ldots 3 \cdot 10^{-5}$ Torr, $\mathrm{U}_{\mathrm{bd}}=9.5 \ldots 12.3 \mathrm{kV}$ this increase is related to the extension of the length of the free path of the electrons that exceeds $50 \mathrm{~cm}$ and it is commeasurable with the longitudinal dimensions of the chamber.

During the experiments carried out to define the Paschen curve using the "ETR PG" we also noticed the instability of the breakdown voltage under fixed vacuum conditions. On average, the breakdown voltage was increased from 3 to $4.5 \ldots 5 \mathrm{kV}$ after 20 practice pulses and the decrease in the capacitor charging rate from 3 to $10 \ldots 15 \mathrm{~s}$. It can be indicative of the need for the conduction of the preliminary training of the chamber and the observance of the specific frequency- periodic mode.

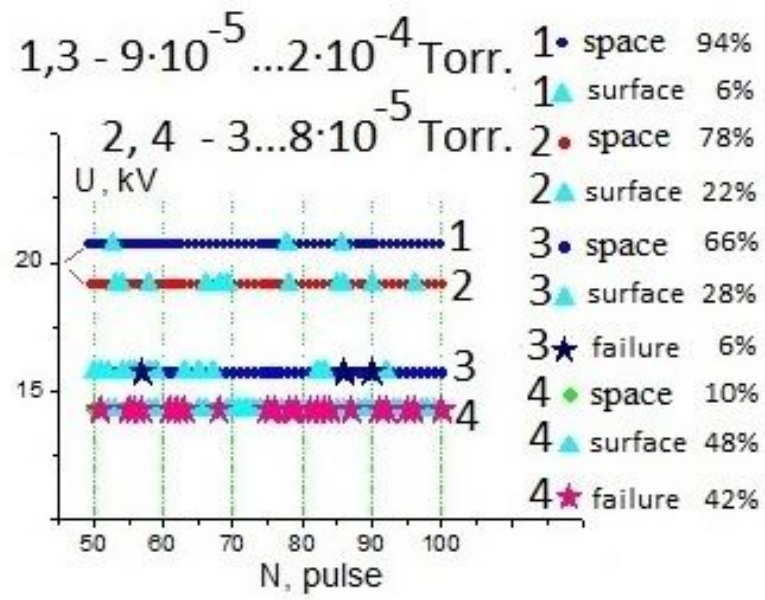

Fig. 5. Statistics of discharge types depending on the amount of pulses, the chamber pressure and the breakdown voltage 
Fig. 5 gives the statistical dependence of the two types of the discharges, in particular the surface discharge and the space discharge and also in the cases when the glow of any type was not observed in the chamber under the condition of the voltage drop on the kilovoltmeter and as a matter of fact, the breakdown of the initiating air discharger occurred. The first $40 \ldots .50$ pulses had a training character. The training of the electrodes and the insulator was carried out under the specific vacuum conditions and at the preset voltage. The dependences were obtained for the two ranges of the working pressure. The first range embraced the pressures of $9 \cdot 10^{-5} \ldots 2 \cdot 10^{-4}$ Torr. These are lines 1 and 3 and the second range embraced the pressures of $3 . . .8 \cdot 10^{-5}$ Torr.

It should be noted that the pulse train ranging from 1 to 100 and more was fed in series and vacuum conditions were varied in specified ranges. It was established that an increase in the operating voltage from 15 to $20 \mathrm{kV}$ for the first pressure range considerably improved the statistics of the discharge of a space type and the failure rate was less than $4 \%$ and the misfires were actually absent. At an increased vacuum and the capacitor bank charge of $20 \mathrm{kV}$ the number of surface breakdowns was increased with no visible glow flooding of the entire chamber. The conditions with low breakdown voltage and high vacuum with the failure count attaining $42 \%$ can be called conventionally unfavorable.

\section{OPTICAL DIAGNOSTICS OF THE PLASMA GLOW}

For the interelectrode distances of up to $10 \mathrm{~mm}$, breakdown voltages occur due to the particles adsorbed on the insulator material surface. It is shown in the scientific paper (5) that in the case of the free path length exceeding the radial size of the dielectric through which the electric breakdown advances the composition of the injected plasma is influenced by the availability of the molecules of residual gas available on the dielectric surface. It means that for the working pressures used for our experiments $\left(10^{-4} \ldots 10^{-5}\right.$ Torr $)$ the plasma composition is defined by the material of the dielectric and that of its surface layer. Hence, in the voltage range of 10 to $15 \mathrm{kV}$ the surface breakdown occurs providing the formation of the plasma flow consisting mainly of the particles of the dielectric material (polyethylene) and water vapors and the content of $\mathrm{H}_{2}$ amounts to about $50 \%$.

Based on the obtained spectral analysis and highspeed video shooting data we showed that the pulsed PG designed for the HEAs operating on the IES principle form the plasma flows consisting mainly of $\mathrm{H}$ and $\mathrm{C}$ atoms and ions.

The experimental testing bench "ETB-PG" enabled the development and introduction of PG that use the dielectric with the radius of $9 \mathrm{~mm}$ that can be easily replaced by other materials (Fig. 6). During the experiments carried out using the plasma guns of the testing bench two specific types of the discharges were observed in vacuum above $2 \cdot 10^{-4}$ Torr that differed by their color spectrum and glow duration and the visual domain of the glow flooding in the chamber (Fig. 7).
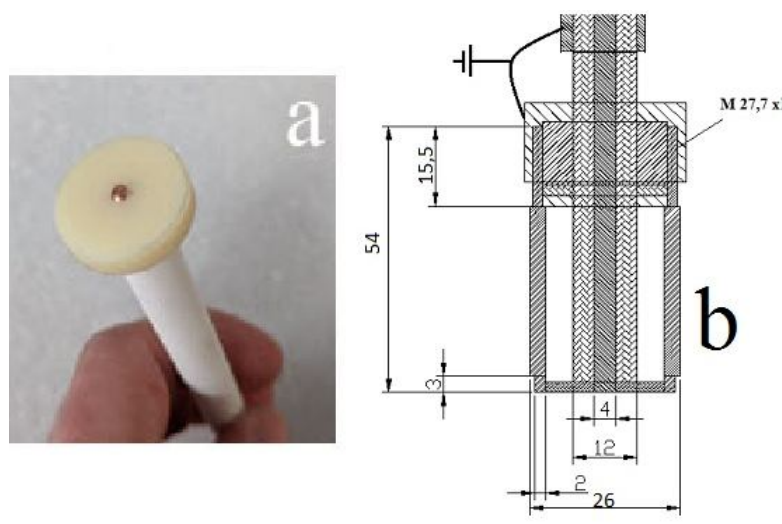

Fig. 6. General view of the PG: a is the $P G$ with the polytetrafluoroethylene dielectric at the end-face, $b$ is the structure of $P G$ arranged in the vacuum section

Conventionally, these discharges can be called the space discharge and the surface discharge, because in the first case the flash visually fills the entire chamber volume and in the second case it is observed in the form of the small torch near the dielectric surface. Seemingly, the radiation color spectrum is defined by the temperature difference and the difference in the composition of atomic and molecular components that were desorbed from the insulator surface and chamber walls and changed to the excited and ionized states during the collisions with the electrons.
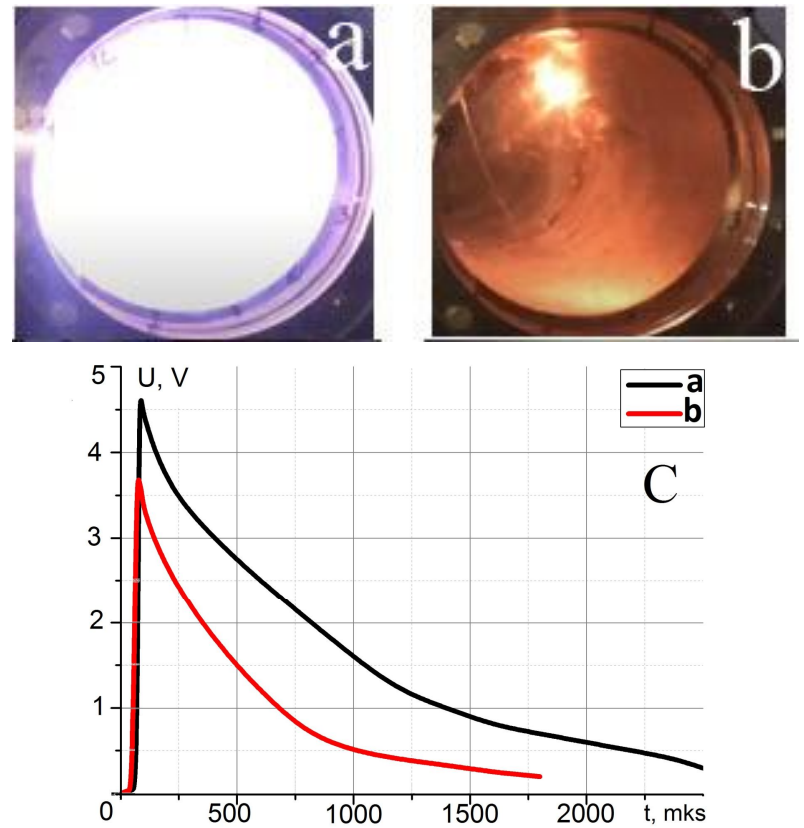

Fig. 7. General view of the glow resulted from space and surface discharges: a is the formation of the space discharge; $b$ is the formation of the surface discharge, and $c$ is the appropriate oscillograms of the glow intensity and duration

The origination of surface and space discharges during the operation of $\mathrm{PG}$ is conditioned by the pressure value in the vaccum chamber and the applied voltage. At a high vacuum and long free path lengths in the chamber of a typical size a certain portion of the electrons gets to the chamber walls including the opposite wall and ionizes the dopped layers adsorbed on it and the wall material. A certain portion of such excited particles is distributed in the chamber volume. The space 
type of the discharge is peculiar for the vacuum in the range of $8 \cdot 10^{-5} \ldots 2 \cdot 10^{-4}$ Torr and $\mathrm{U}$ exceeding $15 \mathrm{kV}$. In the case of the pumping out to get the vacuum of (2..3) $\cdot 10^{-5}$ Torr the space type of the discharge was maintained due to an increase in the surface breakdown voltage. The surface type of the discharge was typically observed at the vacuum of $(2 \ldots 5) \cdot 10^{-5}$ Torr and the voltages of up to $12 \mathrm{kV}$. At the pressures close to the atmospheric value the corona discharge of an increasing intensity was observed between the electrodes whose lifetime considerably exceeds that of the radiation emitted by the above electrodes.

\section{DEFINING THE LONGITUDINAL AND RADIAL RATE OF THE PLASMA PROPAGATION}

To attain an efficient current cutoff that is characterized by a rapid growth of its derivative it is necessary to create first the conductive, long-lived $(\sim 10 \ldots 100 \mu \mathrm{m})$ and sufficiently dense plasma. One of important parameters of the injection process is the plasma propagation velocity in the evacuated chamber volume.

The determination of the characteristic time of the plasma propagation and its sufficient repeatability, in particular, more than $80 \%$ of the total number of pulses depends on the external conditions and discharge circuit parameters. The experimental testing bench "ETR-PG" is used for the refinement of the diagnostic methods and tools that enable the determination of the longitudinal and radial components of the plasma velocity after the pulse discharge on plasma guns under different conditions, see Fig. 8. In the future, these diagnostic tools are planned to be embedded into already operating accelerators.
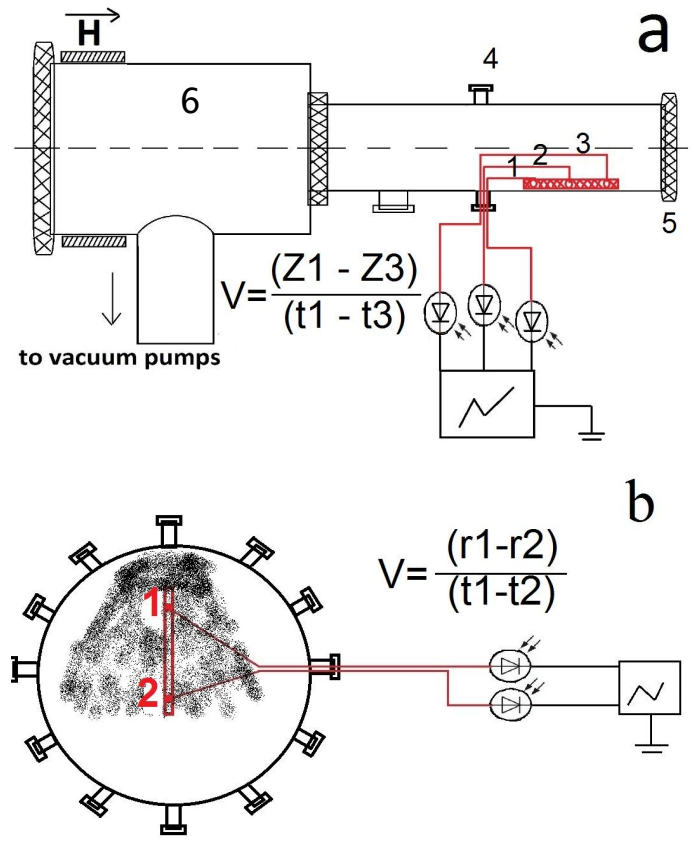

Fig. 8. The sketch of the "ETB PG" with FEMs arranged inside the setup to measure longitudinal (a) and radial (b) plasma velocities.

1 - 3 are light-emitting diodes; 6 is the evacuated chamber of the experimental testing bench "ETR PG"; 4 is plasma guns; 5 is the flange made of polymethyl methacrylat
To measure the longitudinal plasma velocity, the vacuum chamber was equipped with the three lightemitting diodes with the possibility to travel in $\mathrm{Z}$ and $\mathrm{R}$ axes (see Fig. 8,a,b). The operating part of the LED was locked with the electrocorundum tube to prevent the action of the plasma flow and the restriction of the directional pattern and on the opposite side (outside the vacuum chamber) the light signal was received by the photodiode and further it was recorded by the oscillograph.
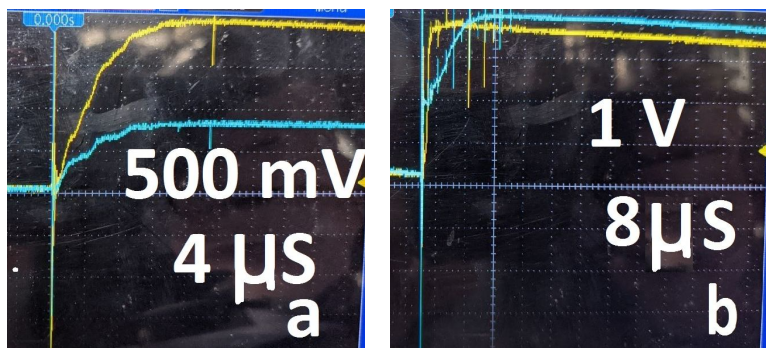

Fig. 9. Glow intensity oscillograms obtained for the longitudinal plasma propagation in the chamber at the pressure of $P=4 \cdot 10^{-5}$ Torr $(a-11 \mathrm{kV}$ :

surface discharge; $b-15 \mathrm{kV}$ : space discharge)

The distance between the sensors was equal to $3 \mathrm{~cm}$ and the distance from the sensor to the chamber wall was $5 \mathrm{~cm}$. The oscillograms in Fig. 9 give the measurement data of the light flow and light flow intensity signals received from the two sensors 1 and 2 (see Fig. 8,a)

The delay time between the two curves was $\sim 3$ and $6 \mu \mathrm{s}$, accordingly. Taking into consideration the fact that the distance between the sensors was equal to $3 \mathrm{~cm}$ we obtain the longitudinal plasma propagation velocity of $\mathrm{Vz} \sim(0.5 \ldots 1) \cdot 10^{6} \mathrm{~cm} / \mathrm{s}$. In addition to the velocity, the attention should also be paid to the signal amplitude. In the case of the space discharge the plasma glow is brighter and it is propagated occupying a larger chamber space. It can be estmated procceding from the difference in the glow intensity on the sensors 1 and 2 .

To measure the radial plasma velocity, we used the system with external focusing lens. The two sensors were arranged at a distance of 1 meter from the plasma source near the end face of the vaccum chamber of the setup and these were directed through the plexiglas flange.

The measurements were taken for the two distances between the LEDs, in particular 4.2 and $3 \mathrm{~cm}$ and in this case the focal distance between the plasma measurement points inside the chamber was 11 and $7.5 \mathrm{~cm}$, accordingly. All the measurements were taken relatively the axial line of the setup (the first sensor was placed at a distance of $5.5(7.25) \mathrm{cm}$ from the plasma gun). The measurement data are given on the oscillogram in Fig. 10 and Table.

The obtained plasma radiation recording data are indicative of that the radial plasma velocities turn out to be 40 to $60 \%$ higher in comparison to longitudinal velocities and attain the values of several units per $10^{6} \mathrm{~cm} / \mathrm{s}$. For the discharge energy range and the distances between the recording sensors in question an increase in velocity is close to the linear. 

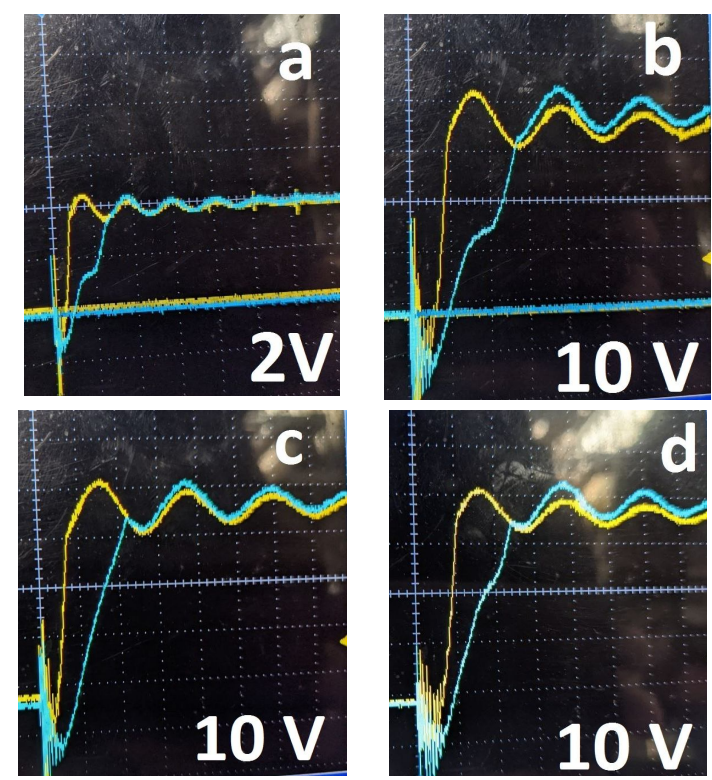

Fig. 10. Radial plasma velocity measurement data depending on the discharge data at the pressure

$$
\text { of } P=4 \cdot 10^{-5} \text { Torr }
$$

$(a-16.5 \mathrm{kV} ; b-18.5 \mathrm{kV} ; c-23 \mathrm{kV} ; d-18 \mathrm{kV})$.

The time scale gradation is $a-4 \mu s ; b, c, d-2 \mu s$

Comparative plasma propagation velocities for different voltages and distances between the sensors

\begin{tabular}{|c|c|c|c|}
\hline $\mathrm{U}, \mathrm{kV}$ & $\mathrm{V}, \mathrm{m} / \mathrm{c}$ & $\Delta \mathrm{t}, \mu \mathrm{s}$ & $\Delta \mathrm{r}, \mathrm{cm}$ \\
\hline 16.5 & $2.75 \cdot 10^{6}$ & 4 & 11 \\
\hline 18.5 & $3.05 \cdot 10^{6}$ & 3.6 & 11 \\
\hline 23 & $4.6 \cdot 10^{6}$ & 2.4 & 11 \\
\hline 18 & $3 \cdot 10^{6}$ & 2.5 & 7.5 \\
\hline
\end{tabular}

For the purpose of verification, the distance between the sensors was changed and the measurement data are given in Fig. 10,d. The data obtained at the voltages of 18 to $18.5 \mathrm{kV}$ show that the result is independent of the distance between the sensors for the given limits of the values.

\section{SPECTRAL ANALYSIS OF THE COMPOSITION OF THE DISCHARGE PLASMA}

Optical measurements were taken when operating one plasma gun using the polytetrafluoroethylene dielectric. Fig. 11 gives the decoding data for the plasma spectrogram.

Since the system is pumped out using the steam-oil pumps with the deposition of $\mathrm{C}, \mathrm{H}$, and $\mathrm{H}_{2} \mathrm{O}$ on the chamber walls, the spectrum explicitly shows the lines of excited hydrogen atoms and ions with the ionization potential of $13.6 \mathrm{eV}$. An increase in the discharge voltage results in the appearance of the lines on the spectrum that correspond to carbon including $\mathrm{C}^{2+}$ (the ionization potential is $24.38 \mathrm{eV}$ ) and also carbon and nitrogen compounds.

However, the spectrum is lacking the lines that correspond to fluoride ions with the first ionization potential of $17.41 \mathrm{eV}$. Such a result can be explained by the limited characteristics of the device (the recording time exceeds the lifetime of the excited state of the fluoride atom and ion) and by that the space discharge develops with a minimum heating of the dielectric surface.

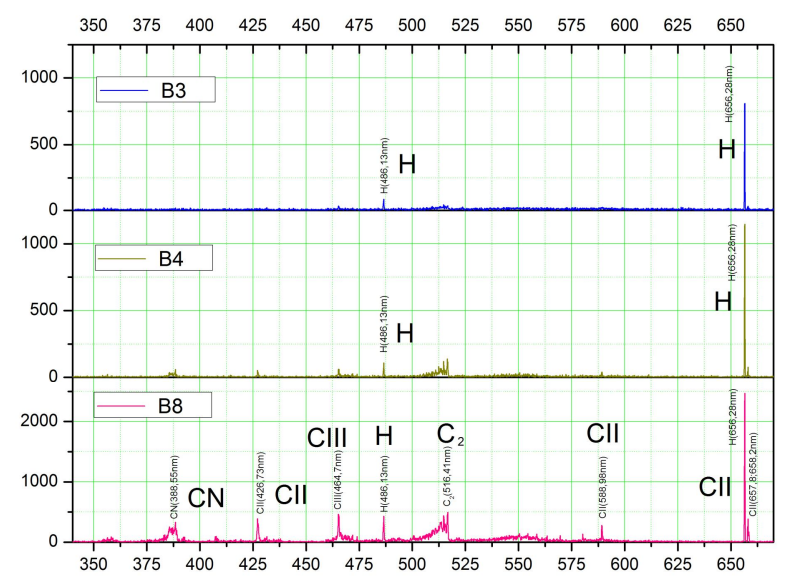

Fig. 11. Optical plasma spectrogram formed during the discharge of the plasma gun with the polytetrafluoroethylene dielectric at different discharge voltages $(B 3-14 \mathrm{kV}, \mathrm{B} 4-16.5 \mathrm{kV}$, and $B 8-19 \mathrm{kV})$

\section{CONCLUSIONS}

The experimental testing bench "ETB-PG" was created to study the designed PG, the parameters of the plasma generated by them and for the refinement of diagnostic tools.

The parameters of the discharge circuit of this setup have been investigated; the values of discharge currents equal to 7 through $25 \mathrm{kA}$ were obtained for the voltage range of 12 to $20 \mathrm{kV}$.

The experimental Paschen curve showed a change in the value of the breakdown voltage from $800 \mathrm{~V}$ to $12.2 \mathrm{kV}$ for the specified interelectrode gap in the working pressure range varying from the atmospheric value to $2 \cdot 10^{-5}$ Torr.

The investigation of the PG equipped with the dielectric made of fluorine plastic showed an opportunity for the formation of the discharges of two types. To obtain the discharge of a space type with the visual occupation of the entire chamber volume by plasma the discharge voltage should be increased to get the value exceeding $15 \mathrm{kV}$ or the vacuum should be maintained at the level of $8 \cdot 10^{-5}$ Torr and lower.

The optical data were obtained for the plasma flow propagation velocity in the axial and radial sections using the photosensors for the plasma radiation recording. On average, the longitudinal velocity component is 3.5 time lower than the radial velocity component.

The plasma glow time during the PG discharge was varied in the range of 2 to $3 \mathrm{~ms}$ and the current oscillogram duration was of $\sim 30 \mu \mathrm{s}$.

The optical spectrogram showed that hydrogen and carbon are prevailing in the plasma composition and double -charged carbon ions appeared with an increase in the discharge voltage.

\section{REFERENCES}

1. L.A. Artsimovich et al. Electrodynamic Acceleration of Plasma Blobs // JETP. 1957, v. 33, p. 3.

2. A.A. Kalmykov. Pulsed Plasma Accelerators in the Book: Physics and the Application of Plasma Accelerators. Minsk, 1974, p. 48. 
3. V.V. Sidnee. High-power Pulsed Plasma Accelerators // Issues of Nuclear Science and Engineering. Series of "Thermonuclear Fusion". 1983, edition 2, p. 12.

4. A.F. Sorokin Electrojet Engine of a Railgun-Based Type // Academy of Sciences of the USSR. No 1626769.
5. N. Khamidov. Electric Discharge Along the Surface of Solid Dielectrics in Vacuum. Tashkent: FAS, 1985, p. 258.

Article received 03.06.2021

\section{СТЕНД ДЛЯ ДИАГНОСТИКИ ПЛАЗМЫ, СОЗДАВАЕМОЙ ИМПУЛЬСНЫМИ ПУШКАМИ С ПРОБОЕМ ПО ПОВЕРХНОСТИ ДИЭЛЕКТРИКА}

\section{Д.В. Винников, В.В. Катречко, В.Б. Юферов, В.И. Ткачёв, С.А. Петренко, В.Т. Фомин}

Создан экспериментальный научно-исследовательский стенд «ЭНИС-ПП» для исследования работы плазменных пушек. Предложена конструкция плазменных пушек со сменным диэлектриком, работающих с перекрытием по поверхности. Определены токи и напряжения разряда в атмосферных и вакуумных условиях. Обнаружено два типа разряда в диапазоне давлений от атмосферного до $10^{-5}$ Торр. Построена экспериментальная кривая Пашена. Установлена статистическая зависимость типов разрядов от количества импульсов, давления в камере и напряжения пробоя. Представлены результаты оптических исследований плазменного потока, создаваемого плазменными пушками в вакууме от $2 \cdot 10^{-4}$ до $2 \cdot 10^{-5}$ Торр. Оценена скорость распространения плазменного потока в аксиальном и радиальном направлениях. Определено время свечения инжектируемой плазмы при разных типах разряда. Получены спектрограммы состава и степени ионизации плазмы.

\section{СТЕНД ДЛЯ ДІАГНОСТИКИ ПЛАЗМИ, ЩО СТВОРЮСТЬСЯ ІМПУЛЬСНИМИ ГАРМАТАМИ З ПРОБОСМ ПО ПОВЕРХНІ ДІЕЛЕКТРИКА}

\section{Д.В. Вінніков, В.В. Катречко, В.Б. Юферов, В.І. Ткачов, С.О. Петренко, В.Т. Фомін}

Створено експериментальний науково-дослідний стенд «ЕНДС-ПГ» для дослідження роботи плазмових гармат. Запропонована конструкція плазмових гармат зі змінним діелектриком, що працюють за принципом електричного пробою по поверхні. Визначені струм та напруга розряду в атмосферних та вакуумних умовах. Виявлено два типи розряду в діапазоні тиску від атмосферного до $10^{-5}$ Торр. Побудована експериментальна крива Пашена. Встановлена статистична залежність типів розряду від кількості імпульсів, тиску в камері та напруги пробою. Представлено результати оптичних досліджень плазмового потоку, що створюється плазмовими гарматами у вакуумі від $2 \cdot 10^{-4}$ до $2 \cdot 10^{-5}$ Торр. Оцінено швидкість розповсюдження плазмового потоку в аксіальному та радіальному напрямках. Визначено час свічення плазми, що інжектується при різних типах розряду. Отримано спектрограми складу та ступеню іонізації плазми. 